\title{
Personnel F
}

\section{Navigating emotion in HR work: Caring for ourselves?}

\begin{tabular}{|r|l|}
\hline Journal: & Personnel Review \\
\hline Manuscript ID & PR-07-2018-0244.R1 \\
\hline Manuscript Type: & Research Article \\
\hline Keywords: & $\begin{array}{l}\text { Emotions, Human Resource Practitioners, Working lives, Participant-led } \\
\text { photo-elicitation, Emotion-focused coping, Narrative }\end{array}$ \\
\hline Methodologies: & Qualitative \\
\hline
\end{tabular}

SCHOLARONE ${ }^{\mathrm{m}}$

Manuscripts 


\title{
Navigating emotion in HR work:
}

\section{Caring for ourselves?}

\begin{abstract}
Purpose - The purpose of this paper is to understand how Human Resource (HR) practitioners subjectively experience emotions in their working lives and how they navigate emotionally challenging work.
\end{abstract}

Design/Methodology/Approach - A narrative methodology and participant-led photo-elicitation methods were used with five HR practitioners from different sectors to uncover experiences of emotion in their work.

Findings - Participants describe themselves perceived by non-HR employees as non-emotional human beings, expected to 'take' emotional expression from others, but display little themselves. HR practitioners use emotion-focused coping strategies, both self and team-care, to cope with the emotionally challenging work inherent in their role.

Research limitations - As a pilot study of five participants, further research is needed to strengthen the findings, however the in-depth qualitative methods used provide rich insight into their working lives.

Practical implications - HR practitioners' wellbeing should not be taken for granted or overlooked in organisations. Opportunities for informal networking with HR communities and training/coaching interventions could provide support on approaches to the emotional challenges faced. 
Originality/Value - This paper provides insight into how HR practitioners experience the challenges of their work, in contrast to mainstream research emphasising the impact of HRM policy and practices on employees and organisations. Attention is drawn to the subjective experience of emotion, rather than the mainstream objectification, managerialisation and generalisation of emotion.

\section{Introduction}

Human Resource (HR) practitioners hold emotionally challenging roles in organisations. They are expected to handle difficult and sensitive people issues (Frost, 2003), yet little academic research considers the impact and influences of performing the HR role on themselves or how they do this (O'Brien and Linehan, 2014). This is surprising given the welfare roots of the role and increasing contemporary interest in organisational wellbeing (Kowalski and Loretto, 2017). In addition, HR practitioners are not at the forefront of emotion research because they are not in 'front-facing' service roles nor deemed to face particularly intense emotional or life and death situations. Within the Human Resource Management (HRM) literature debates persist as to where HR is positioned in organisations, further complicated by a plethora of role typologies (Marchington and Wilkinson, 2012), rather than considering the experiences of practitioners themselves. The contribution of this paper lies at the intersection of HRM and organization emotion literature, uncovering the emotional challenges HR practitioners face in their day-today working lives. The aim is to better understand participants' subjective experiences of emotions in HR work and how they navigate such work: an area under-explored to date. 
Legge (1978) was one of the first scholars to draw attention to the ambiguous nature of the 'Personnel' role over 40 years ago. She found personnel managers' work reactionary due to a lack of success criteria, duplication with line managers' responsibilities, and role holders viewed as representing both management and employees. The shift from what was an administrative 'Personnel' function to an increasing strategic HRM focus in the 1980s and 1990s, aligned HR practitioners' work with organisational goals, arguably at the expense of employee interests (Hope-Hailey et al., 2005; Keegan and Francis, 2010). Contemporary academic research continues to debate the tension and challenges inherent in HR roles, such as whether HR practitioners represent employee or organisational interests, what value they add as strategic business partners (Ulrich, 1997; Ulrich and Brockbank, 2005), and whether occupational tensions can be resolved (Cappelli, 2015; Sandholtz and Burrows, 2016; Sheehan et al., 2016). More critical perspectives suggest being aligned to organisational goals has diminished the focus on the human' in HR work (Bolton and Houlihan, 2007; Johnsen and Gudmand-Høyer, 2010). Despite this, HRM theorizing is often in contrast to the reality of day-to-day working lives and few researchers consider HR practitioners' personal experiences, and even less their emotions. How does it feel to work as an HR practitioner? How do they subjectively experience and cope with the various emotional challenges they face?

A narrative methodology underpinned the study and interviews based on a participant-led photo-elicitation method used to access emotional experiences. This is a participatory method, where photographs made by participants rather than the 
researcher stimulated discussion (Meyer et al., 2013; Shortt and Warren, 2017) and generated narratives around participants' subjective experiences of emotions in HR work. Thematic narrative analysis was used to interpret discussions, uncovering unexpected narratives of self and team care, as participants acknowledged that apart from themselves, the only people they could rely on for support in the face of emotionally-draining work were HR peers or immediate family.

This paper is structured as follows: Firstly literature is reviewed on organisational emotion and then connected with the HR role. Secondly, the methodology and methods used are justified, followed by an explanation of how the study was conducted and interpreted. Findings are presented as three narrative themes of difficult work, self-care and team care. The main implication is that, given the emotionally challenging nature of their work, those providing welfare/emotional support for others should not be overlooked.

\section{Emotion perspectives}

This section addresses three main threads: how emotions are theorized in the literature from a 'social perspective', the subjective experience of emotion, and approaches to navigating emotion.

\section{A social approach to emotion in organisations}

Emotions can be difficult to understand as "they are complex and intricate phenomena" (Burkitt, 2014, p. 15). Fineman (2003) groups emotion research into four broad and differing perspectives - biological, psychodynamic, cognitive and social - which covers a range of disciplines, philosophical approaches and 
methodological applications. Studies taking essentialist perspectives, such as psychodynamic approaches, are concerned with identifying, measuring and investigating individual and biologically-set emotions (Fineman, 2005) where emotions are distinct phenomena in themselves (Burkitt, 2014). Interpretive perspectives, in which this study is located, are concerned with what sits 'outside' individual emotion, for example generated through what is socially and/or organisationally desired, (Fineman, 2005). Social perspectives foreground cultural setting, feeling rules and scripts, language and social expectations (Fineman, 2003). Taking such an approach acknowledges that interactions with others cause emotions and the significance of emotion is evaluated in the context of relationships with others and their cultural importance (Parkinson, 1996).

In simple terms, the subjective experience of emotion can be explained as "how people say they feel", which is observable and becomes an objective indicator of emotion (Scollon et al., 2011, p. 854). However, from an interpretive perspective experience is not detached, nor can it be studied as such. Experiencing emotion "locates the person in the world of social action" i.e. emotion both "refers back to" that person's experience and is experienced in relation to others and the specific context of that experience (Denzin, 2007, p. 3). In addition, the subjective experience of emotion varies between individuals and may be shared. This places importance on the meanings individuals give to their experience, assuming that what we experience as emotions are a sign of what is meaningful (Humphrey et al., 2015). This study will not objectivise participants' emotions by categorising them into universal groups like in psychological approaches to emotion (Turner, 2009), simplifying their meaning or experience. In adopting a subjectivist ontological 
positioning, meaning is located in everyday experiences and interactions between people and their world (Cunliffe, 2011). It is not possible to generalize participants' experiences and realities because they are situated in a context. Rather, the narratives shared by participants enable deeper understanding of their experiences, which can, and do, resonate with others.

\section{Navigating emotion}

Our experience of emotions can lead to efforts to alter the effects of that experience. Emotion regulation is defined as "the ways individuals influence the emotions they have, when they have them, and how they experience and express these emotions" (Gross, 1999, p. 557). Such a definition implies emotions need 'managing' (Burkitt, 2018). Alternatively, coping can be defined as, "an individual's efforts to master demands (conditions of harm, threat or challenge) that are appraised (or perceived) as exceeding or taxing his or her resources" (Monat and Lazarus, 1991, p. 5). Such efforts or coping mechanisms are suggested conscious acts, a way of protecting the self from "the emotional consequences of adversity" (Cramer, 1998, p. 920). In other words not 'regulating' emotional expression or experience because an individual feels they should, but a means of coping with the stressor, or navigating that experience.

Coping mechanisms tend to be grouped into two categories, problem-focused and emotion-focused. The former occurs where attempts are made to take constructive action in relation to a stressor, the latter is invoked where it is perceived the stressor cannot be managed, and needs to be endured (Garnefski et al., 2001). Problemfocused strategies include; confronting the stressor, accepting responsibility and 
creating action plans, whereas emotion focused strategies include distancing and avoidance, self-control such as by keeping feelings private, seeking social support from others, and positive appraisal (Folkman et al., 1986). Emotion-focused coping therefore is a means of reducing emotional tension and/or 'managing' emotions within the self rather than the external stressor (Carver et al., 1989). This does not however mean emotion-focused coping is always a solitary act. Seeking support from others, such as sharing emotions with confidantes or with a team, might be used for purposes such as "venting" or releasing emotions to others to gain their empathy or moral support, or in a more practical way to gain advice (Carver et al., 1989). Socially sharing negative emotions is suggested to lead to positive outcomes for both individuals and team members, strengthening existing workplace relationships (Yang and Kelly, 2015). Korcynski (2003) identified 'communities of coping' where call centre workers collectively released workplace tensions, away from the formality of management control.

\section{Emotion in organisations and HR work}

Though today emotions are seen to have a legitimate place in organisational life (Lindgren et al., 2014) they are still studied from a perspective of rationalisation and control (Bolton, 2005). Hochschild's (1983) influential research highlighted how organisations control emotions, where 'emotional labourers' display emotions on demand, smile in customer interactions and demonstrate empathy towards angry customers. Though her work challenged earlier thought privileging the rationalization of emotion, it conversely demonstrated privileging the commodification of emotions for commercial gain (McMurray and Ward, 2014). Researchers tended to then view emotional expression in organisations as a phenomenon to be performed. 
Popularised theories such as emotional intelligence also suggest emotions can be recognised and managed (Goleman, 1995), and positive organisational psychology encourages a reframing of negative thinking to improve individual and organisational performance (Fredrickson, 2003). Organisational actors face pressure to adhere to organisational/cultural norms of emotional expression perceived 'organisationally desirable' (Fineman, 2005). Therefore 'un-desirable' emotions are not acknowledged or accepted as being part of day-to-day working lives.

HR practitioners' work is emotionally-laden. They are expected to handle difficult and sensitive people issues in an empathetic way (Frost, 2003), and be neutral factfinder when solving employee problems (Steers, 2009). They regularly engage in emotionally challenging tasks impacting on employees' personal lives, such as downsizing (Clair and Dufresne, 2004), disciplinaries (Jones and Saundry, 2012), and bullying complaints (Cowan and Fox, 2015). They face emotions of employees and line managers, the latter who may lack the skills to carry out disciplinary action, requiring 'hand-holding' (Jones and Saundry, 2012) and extensive emotional support. Although these studies consider the HR practitioner role in such tasks, their emotional experience is not the focus.

Academic research has considered the impact of handling emotions on other occupations such as nursing (Bolton, 2000), healthcare professionals (Crego et al., 2013), counsellors (Mann, 2004); notwithstanding the emotional labour literature which extends into occupations beyond its service sector origins. Scholars taking an emotional labour lens consider the commodification of emotions, i.e. their control by organisations and the effects of such on 'emotional labourers' (Hochschild, 1983). 
Despite continuing popularity, some argue emotional labour has reached methodological saturation (Grandey and Gabriel, 2015). In contrast to emotional labour, this study highlights how HR practitioners subjectively experience emotion at work. It will consider how HR practitioners feel about their work, what meanings they give to that experience, what challenges they perceive in relation to their emotions, and how they cope with them. This requires a reframing from the emotional labour literature to uncover 'everyday' human emotions. In addition, empirical studies exploring the emotional challenges of the HR role are sparse with a handful of exceptions (see Hiillos, 2004; Kulik et al., 2009; Metz et al., 2014, O’Brien and Linehan, 2014, 2018), which are summarized below.

Hiillos (2004) identified five emotion-handling strategies used by HR managers, such as adopting mediating and counselling roles, and/or distancing themselves from employees' emotions. Her study restricts emotion to what HR managers considered 'crisis situations'. Two further studies focus specifically on the wellbeing effects on HR practitioners as 'toxin handlers' taking a psychological framing, concluding that 'toxin handling' does not necessarily result in stress or emotional exhaustion (Kulik et al., 2009; Metz et al., 2014). O’Brien and Linehan's $(2014,2018)$ empirical studies investigate the emotional labour of HR managers using grounded theory methodology. One significant finding is that HR managers are required to meet emotion display rules to achieve tasks and support organisational relationships with line managers. In contrast to 'front of house' employees they argue the management of feeling is more complex due to the unscripted and autonomous nature of their work. Though insightful in highlighting external expressions of emotions against the emotional labour construct, their study emphasises how emotions are managed through control of their external display/expression rather than how emotions are 
experienced. In doing so, they overlook the unconscious and relational dimensions of emotion (Theodosius, 2006). HR practitioners' behaviours and emotional display expectations are categorised into roles, objectivising their feelings. By contrast, the present study provides a more in-depth, nuanced account of emotional experience i.e. how participants subjectively experience emotions and the relationships between people and the world around them. Having considered existing empirical work, the next section explains the methodology used to better understand subjective experience.

\section{Methodology}

Narratives are ways of communicating that enable us to know and interpret the world (Cunliffe et al., 2004) and therefore a narrative approach lends itself to an interpretive perspective. In seeking to access and understand the emotional experience of work, Boudens (2005) analysed narratives from secondary data sources about experiences of work, resulting in rich pictures of what aspects of work generate emotion. Intense emotional experiences were accessed indirectly through figurative language (Boudens, 2005), like how stories expose our emotions, (Ulus and Gabriel, 2016). This study aims to seek expressions of emotions in participants' narratives that help account for how HR practitioners, as Fisher (1984) suggested, justify, guide and make sense of their individual lives. A subjectivist positioning, assumes those emotional experiences are subjectively constructed in an organizational context. This means a focus on content - what is said, and its context, in order to develop contextualised understandings of the narrative (O'Connor, 2000). 
Photo-elicitation, where a photograph is used as a prompt to elicit opinions in a research interview (Harper, 2002), is a method that can uncover otherwise hidden emotions (Höykinpuro and Ropo, 2014). Images can encourage talk when more than words are needed (Allen, 2015) as they, "mine deeper shafts into a different part of human consciousness than do words-alone interviews" (Harper, 2002, p. 23). Acknowledged as enabling a more in-depth understanding of participants' subjective experiences, participant-led photo-elicitation is based on photographs participants themselves have generated that are then used to evoke discussion in an interview (Warren, 2018). There are challenges in encouraging participants to express 'private' emotional experiences through language alone (Sturdy, 2003; Wierzbicka, 2009). The words used to label emotions may not enable us to articulate the breadth of emotions experienced. Photographs can overcome this by acting as visual prompts that can extend the language and explanations available to participants, by surfacing their taken-for-granted experiences: experiences that both participant and researcher might otherwise overlook (Clark-IbáÑez, 2004). Exploring what might be perceived as mundane encourages thinking beyond the image of the photograph (Slutskaya, et al., 2012; Shortt and Warren, 2012). Participants gain the distance necessary for standing back and examining their own lives as they reflect on their experiences in a way they have not done before (through discussion about photograph meaning).

\section{The Study}

The in-depth pilot study with five participants reported here was part of a larger research project on workplace emotional experience. The participants held organisational HR roles at different levels, ranging from HR Director, Manager and Advisor, in a diverse range of sectors including Not-for-Profit (Hospice), Public 
(Further Education) and Private (Professional Services, Healthcare, and Transport). Participants volunteered through the researcher's personal network on Linkedln. They were asked to bring up to 10 photographs which 'show how it feels to work in HR'. Each participant took between 7-10 photographs. At interview the photographs were discussed in the order taken by participants, to preserve any narrative sequence. Interviews were unstructured, driven by the participant's explanation of photograph meaning, each lasting between one to two hours. These in-depth discussions about photograph meaning elicited rich data.

\section{The interpretive process}

On completion of the interviews, photographs and transcripts of interviews were interpreted together as one body of data by the sole researcher. The first stage of analysis involved capturing image content or what the photograph was of (Edwards and Hart, 2004). The photographs ranged from cups of tea, tissues, in-trays and bins, to 'selfies', and photographs of hand drawings: stick people striking and an island. However, what the photograph was of was very different to what the photograph represented (Shortt and Warren, 2017). Participants stated the photographs 'represented' their emotional experiences yet in isolation the objects were meaningless (Edwards, 2002). As such, content-analysis of the photographs was not conducted as doing so would abstract it from the context and personal experience it represented. Photograph purpose was to elicit participants' views and opinions about the topic; a dialogical approach (Meyer et al., 2013). Secondly, the researcher noted how participants labelled the emotional experiences that the images represented, then unpacked the subsequent narratives, highlighting quotes 
resonating with the topic of emotions in HR work followed by thematic narrative analysis.

Thematic analysis enables identification of patterns in the narrative, what Smith (2015, p. 216) suggests is a means of identifying, "the common theme(s) or thread(s) in each story". However, Smith cautions against further breaking down the narrative into smaller codes to avoid fragmenting the narrative. The researcher therefore aimed to "keep the 'story' intact" (Riessman, 2008). Within narrative, thematic analysis prioritises content, 'what' is said, rather than analysing narrative structure or 'how' the narrative is told (Maitlis, 2012). Theorizing occurs across the participants' narratives, not solely in individual cases (Riessman, 2002).

Common themes were identified in the content of each narrative and across the five participants' accounts. This interpretive process was not about quantifying the number of occurrences of each theme, but highlighting "something important in relation to the research question" (Braun and Clarke, 2006, p. 82) and creating a resonant narrative. Narratives of isolation and an inability to talk to others about their work were important due to the confidential nature of the HR role. Participants faced the difficult task of enacting work on behalf of the organisation, which had emotional consequences for employees. Various coping strategies were deployed by the participants to navigate their work. Across participants' accounts, three common themes were identified: 1. doing difficult emotionally-laden work which resulted in 2. self-care and 3. team-care. Participants shared having to look after themselves as no-one else would, using HR peers and/or their own line managers for support.

Alongside generation of themes, the interpretive process demonstrated the complexity of understanding emotional experience. Emotions were categorised in 
one way by the labels that participants gave each photograph. Yet when unpacked participants' narratives led to different emotions than those initially labelled, because they were interwoven within lived experience. The labelling of the photograph with an emotion was merely a 'way in' that revealed a more complex understanding of their working lives. For example, one participant struggled to label an emotion when describing his drawing of stick people on strike which represented 'conflict'. Unsure of the emotion he stated 'frustration'. He elaborated, explaining how he and other non-striking employees were required to cover for striking employees and he experienced feelings of guilt, justifying his actions as, "the needs of the business so I've kind of just put that front on really". In summary, emotions were not easily labelled, and in line with the interpretivist stance of this study, have a multiplicity of meanings.

\section{Findings}

Participants' narratives demonstrated a complex web of interconnecting emotions and experiences. The three narrative themes also overlapped when discussing photograph meaning. This is illustrated through narratives elicited from four photographs; stress balls, a box of tissues, a drawing of an island and a team photograph. The following four accounts were chosen from the rich data set as they demonstrate thematically coherent examples of the narratives and resonated with the researcher. All names are pseudonyms.

\section{Account 1 - Feeling stressed and 'wonderful'}

Alan is a sole HR Manager in the not-for-profit sector with 12 years' HR experience. One of his photographs was a bag of stress balls positioned on a copy of an HR magazine featuring a cover story about employment tribunal claims. Unlike the 
surface meaning of the image, a device to cope with a stressful situation, his narrative went deeper as he shared four separate narrative accounts, which stem from discussion about one photograph, expressing a range of emotion experiences.

[insert photograph 1 about here]

Photograph 1 - "stress relief"

The first was triggered by explaining the meaning of the photograph. An employee had threatened an employment tribunal claim and he shared his recollected feelings in response,

I think maybe we were looking at early conciliation stuff at the time and I thought d'ya know actually I just need a stress ball, because I was so frustrated with that [...] not with the early conciliation process but with the potential claim. I think I took that quite personally... I am a little bit like that, it's probably one of my faults, I'm, you're sort of, you do your best because you try your best with people, to get the right outcome and do things in the right way, when you get a knock back it can take you quite badly really, and I just, yeah, that just hit a chord with me.

He follows this with a second account of how he copes with such emotionally challenging work, articulating self-care,

I've tried to rationalise things, logically and just sort of try and sort of have 5 minutes with myself, or l'll walk around the garden and just take a bit of time just to compose and sometimes you come back from a particularly stressful 
meeting, you just need a minute...you just need to just blow off some steam [...]. I've got very supportive colleagues you know, l'm quite close to the Finance Manager because we deal with payroll a lot, so we quite often will sort of use each other I suppose.

The third account exposes the narrative theme of difficult work; illustrated through implementing a sickness policy change, and the emotions expressed towards him,

When I was here 3 months we started consultations to reduce sick pay. And that I found really quite stressful because l'd never led on something like that before, l'd always been part of the process, never the person that's done the report, done the stats, told staff what was going to happen, gone through the consultation period, took the venom that comes back to you.

\begin{abstract}
Alan is the recipient of employees' anger, experienced strongly as "venom" and further described as "quite difficult to handle....it was definitely stressful". He ends stating, "you just kind of pull through it and but l'm lucky l've got a supportive Director and also very supportive CEO", a social means of coping (Carver et al., 1989).
\end{abstract}

His fourth account articulates positive experiences with employees, "getting people back to work after things like mental health issues" stating, "the employees felt so good they want to hug you". He describes his feelings in response, "that shows you've done something right, through to supporting to getting things in place for them. So that's wonderful".

In summary, discussion about the meanings of the photograph elicited four separate identifiable but interconnected experiences. All three narrative themes emerge from explanation of photograph meaning, doing difficult work, both self and team-care.

Self-care is illustrated elsewhere in his interview, when discussing a different photograph's meaning, a cup of tea on his desk, where he describes the conscious act of taking a break to "sit back and just have a minute [...] and to be comforted by 
a cup of tea". He acknowledges the importance of looking after himself, "if I don't look after myself there's no-one else that's gonna do that". Alan recalls a breadth of emotional experiences, from feeling hurt, taking employee actions personally to, "feeling wonderful". The complexity of emotional experience is illustrated through their varying intensity, from experiencing "venom" to other "difficult to handle" experiences. Different emotions are experienced simultaneously, for example feeling both frustrated and hurt. These experiences and emotions were elicited through discussion about a photograph of mundane objects.

\section{Account 2 - Feeling unemotional}

Anna, an HR Advisor in Education with 5 years' HR experience, discussed the meaning of a photograph of a box of tissues. She works in a small HR team alongside the HR Manager. Though on the surface it might seem an obvious choice of image, that tissues are used to comfort upset employees, her explanation of image meaning was unexpected,

[insert photograph 2 about here]

Photograph 2 - "sometimes you just feel like you need a tissue"

Researcher: why did you take that photo? 
Anna: I think sometimes for two sides, cos obviously you're dealing with other people's emotions and sometimes a lot of the situations that you come across are quite upseting, so it can be that side of it, being there to support an employee going through something difficult to advise and to comfort. Also I think quite often it feels like other people don't think you're a person, and you don't have any emotions... at all. So they feel like they can speak to you how they want and behave towards you however they want. I think sometimes you just feel like you need a tissue.

She illustrated further,

Like today l've been shouted at by two people. I think sometimes people can be so incredibly rude to you and you're just expected to take what they've said to you and never are you expected to say, 'don't speak to me like that' or you know, 'if you'd like to come back to me when you're in a better frame of mind'. No, you just have to kind of deal with their barrage of abuse at you and then try and like smooth it over.

The photograph represents Anna's perception that others fail to see her as a human being and express emotions towards her such as anger that she experiences as hurtful (needing a tissue in response). She describes an expectation to 'take' others' emotions, i.e. remain neutral and not challenge back, even to a "barrage of abuse" but neutralise the emotion or "smooth it over". Like a tissue, she absorbs strong negative emotions from others. Her earlier discussion about photograph meaning suggests that privately she might express her 'true' feelings as the tissues are used to wipe away her own tears, a visual reveal of her private self-care. She perceives no-one else would think to care for her.

\section{Account 3 - Feeling "like Switzerland"?}

Anna also made a drawing of an island which she photographed, describing its meaning as illustrative of the difficult position HR practitioners hold trying to be 'neutral' parties,

I think me and my boss would describe how we try to be at work. It's not a great depiction of this cos that's just an island, I drew an island, but like 
Switzerland. So well, we say that's how we're supposed to be but I thought an island is a nicer drawing. Because you've got to be impartial on both sides.

[insert photograph 3 about here]

Photograph 3 - "trying to be an island"

The role expectation to hold confidential information led to feelings of isolation,

I think like from an emotional point of view as a person, I think...trying to be an island and be so that people can come to you for advice, know that it's going to be confidential, trust in you for giving good advice but also trusting you to be confidential...it can be quite isolating that's why I drew a little island [...] it can be quite lonely, particularly as we're such a small department.

Using positive reappraisal with her boss illustrated team care/social coping (Folkman et al., 1986), but Anna's perception was that they had no friends at work due to the confidential nature of their work,

We want to be good at our jobs, we want to do a good job, we want to be positive, so to try and keep doing that in an environment that doesn't really want that, can be....so it can be both, it can be 'right come on we're gonna, let's not let this get to us, let's not let it get us down' and it's like 'we've got a good way of working, we're gonna be positive, we're gonna make a difference, we're gonna change things'. But then it can be like 'ooh we're on our little island; we've got no friends'.

Despite having each other, her final sentence suggests loneliness. Her perception is of being 'outsiders' despite being organisational members. 


\section{Account 4 - The "mindfulness mantelpiece"}

Sarah is an HR Director in Professional Services with 10 HR staff. Her "support network" was her HR team, who created an informal social space,

So we decided to make a fireplace out of boxes, cos we've got a lot of space and a lot of walls, and they were a really creative bunch my team, so they actually started making bricks, and sticking them on .... And we now have the sofas around it. So we've taken all the Christmas decorations down but we've kept it because it's quite nice to go and sit there occasionally and have a debrief. Which is nice. Time to talk [...]. We did quite a lot of mental health last year, because mental illness was our charity of the year [...] I think since then we're all very much more sort of open to say, 'hey, how are you doing?' and checking in with people and things like that, which is nice. But yeah generally the team are great. They're very supportive of each other, they have to be, and of me.

She brought to interview a photograph of a photograph which sits on the makeshift fireplace her team call "the mindfulness mantelpiece" (not reproduced here for reasons of anonymity). The photograph shows Sarah with her smiling team, wearing Christmas jumpers. Initially describing photograph meaning as pride in her team, her narrative is one of team-care where the HR team use this space as respite from difficult work because "they have to". These last two accounts contrast emotional experience: the homeliness of the hearth and relating support versus the isolation represented by the island. This demonstrates the relational and contextual nature of the subjective experience of emotion.

\section{Discussion and conclusion}

This section sets out the relevance of the findings in relation to the emotional experiences of HR work, before concluding with some implications for organisations.

Participants selected photographs which elicited narratives surrounding their emotional experiences, signalling what is meaningful for them (Humphrey et al., 
2015). Photographs of mundane objects visually revealed their personal feelings about their experiences of work, and discussions about their meaning highlighted the unconscious and relational dimensions of emotion (Theodosius, 2006). These experiences are constructed in relation to the social and cultural context in which they found themselves. For example, as HR manager leading consultations to reduce 'sick pay', Alan found himself in unfamiliar territory, solely responsible for implementation. He perceived himself, not the Directors that asked him to make the changes, as the target of employees' angry responses, because they were not present in employee consultations. Rather than assuming that HR tasks are devolved to line managers, thereby removing emotional encounters from HR practitioners' work (Renwick, 2003), in a small organisation this was his responsibility. He accepted the task as something he had to "just kind of pull through", failing to acknowledge that he sought emotional support from the organisation's Directors who had set him the difficult task.

In contrast to critical HRM scholars accusations that HR practitioners' alignment to organisational goals has diminished their focus on the human (Bolton and Houlihan, 2007), participants' perceived other employees as treating them as non-emotional human beings. They perceived themselves a face-less HR function, expected to 'take' emotional expression from others, but display little emotion themselves. NonHR employees were less conscious of expressing their feelings. Participants articulated emotion-focused coping strategies, a sense of having to 'endure' the stressor rather than take action to change the situation they found themselves in (Garnefski et al., 2001). For example, conscious self-care where they acknowledged the need to "have five minutes with myself", or have a cup of tea, signalling a need for individual or social respite (Stroebaek, 2013). These coping strategies are 
examples of 'escape - avoidance' where people make "behaviour efforts to escape or avoid" and of self-control, by keeping their feelings private (Folkman et al., 1986, p. 995).

Of course, they are not the only employees who might use such strategies but participants articulated specific organisational conditions more difficult to navigate due to the expectations of their role. For example, the confidential nature of their work resulted in being able to 'vent' or makes friends with few people outside of HR teams. Being the person to whom others felt they could express their anger towards, participants felt they could not express their 'true' feelings back in response.

However, they relied on social support as a further emotion-focused coping strategy (Folkman et al., 1986). In smaller teams, this was with one or two HR colleagues or confidantes outside the HR function. Where the context was a larger HR team this was easier, and in Sarah's case physical space was created for social and emotional support amongst HR peers. Fineman (2003) refers to such informal spaces as 'emotionalized zones' to share and express emotions, rather than deliberately designed break-out spaces. In these spaces HR peers came together like Korcynski's (2003) 'communities of coping', to socially share negative emotions (Yang and Kelly, 2015) and experiences. When they remembered they took time out for themselves, either individually or in peer groups, using devices to protect the self from harmful emotions (Cramer, 1998). Though academic research argues emotions are now legitimised (McMurray and Ward, 2014), this study highlights use of techniques that rationalise the expression of negatively perceived emotions; compartmentalised to 'safe' physical spaces or reframed through 'positive appraisal' (Folkman et al., 1986) where they "put on a front", or "tell themselves to be positive". 
Given that the study's aim was to understand participants' subjective experiences of emotion, from an interpretivist epistemological positioning, possible interpretations are offered with a multiplicity of meanings. As Denzin $(2007$, p. 5$)$ states, "the labels applied to emotional experience are always shifting and are subject to new or different interpretation". It is therefore not possible, nor was it intended, to generalise their experiences. However, expressions of emotions in participants' narratives were identified that help account for how HR practitioners in this study justify, guide and make sense of their individual lives. In communicating details of how they do and make sense of their work, they exposed the complexity of emotional experience.

This paper contributes to HR research by furthering understanding of how HR practitioners experience and deal with their emotions, thus 'humanizing' them. It fills a gap in HR research, which tends to be objectivist and focused on roles and practices. Previous research into how HR practitioners do their work is limited (O’Brien and Linehan, 2014). The study's findings are significant in highlighting how HR practitioners engage in emotion-focused coping strategies of self and social support to deal with the emotional stress they face in their work. In addition, as studies using participatory photo-elicitation methods are sparse (Warren, 2018) this paper highlights a means of accessing emotional experience, bringing the visual into discursive narratives.

The unique nature of HR practitioners' roles in terms of dealing with a range of emotionally-laden activities sets them apart from other employees. As a result of the study findings, it is proposed that organizations should acknowledge the challenges that HR practitioners face in taking steps to address their own welfare without affecting their organisational credibility. Managers of HR teams should consider their welfare, rather than only ensuring they attend to the welfare of others in 
organisations. Training and coaching interventions could help in handling emotionally demanding situations (Richter et al., 2016). For example, how to address emotional challenges and the isolation HR practitioners may feel through professional support networks that could provide a forum for discussion, to not only 'vent' but also gain advice and socially share experiences.

\section{References}

Allen, L. (2015), "Losing face? Photo-anonymisation and visual research integrity", Visual Studies, Vol. 30 No. 3, pp. 295-308.

Bolton, S.C. (2000), "Who cares? Offering emotion work as a 'gift' in the nursing labour process", Journal of Advanced Nursing, Vol. 32 No.3, pp. 580 - 586.

Bolton, S.C. (2005), Emotion Management in the Workplace, Palgrave Macmillan, Basingstoke.

Bolton, S.C. and Houlihan, M. (2007), (Eds.), Searching for the Human in Human Resource Management, Palgrave Macmillan, Basingstoke.

Boudens, C.J. (2005), "The story of work: A narrative analysis of workplace emotion”, Organization Studies, Vol. 26 No. 9, pp. 1285-1306.

Braun, V. and Clarke, V. (2006), "Using thematic analysis in psychology", Qualitative Research in Psychology, Vol. 3 No.2, pp. 77-101.

Burkitt, I. (2014), Emotions and social relations, Sage, London.

Burkitt, I. (2018), "Decentring emotion regulation: From emotion regulation to relational emotion", Emotion Review, Vol. 10 No. 2, pp. 167-173.

Cappelli, P. (2015), "Why we love to hate HR....and what HR can do about it", Harvard Business Review, Vol. 93 No. 7/8, pp. 54-61.

Carver, C.S., Scheier, M.F. and Weintraub, J.K. (1989), "Assessing coping strategies: a theoretically based approach", Journal of Personality and Social Psychology, Vol. 56 No. 2, pp. 267-283.

Clair, J.A. and Dufresne, R.L. (2004), "Playing the grim reaper: How employees experience carrying out a downsizing”, Human Relations, Vol. 57 No. 12, pp. 15971625.

Clark-Ibáñez, M. (2004), "Framing the social world with photo-elicitation interviews", The American Behavioral Scientist; Vol. 47 No. 12, pp. 1507-1527.

Cowan, R.L. and Fox, S. (2015), "Being pushed and pulled: a model of US HR professionals' roles in bullying situations", Personnel Review, Vol. 44 No. 1, pp. 119139. 
Cramer, P. (1998), “Coping and defense mechanisms: what's the difference?", Journal of Personality, Vol. 66 No. 6, pp. 919-946.

Crego, A., Martínez-Iñigo, D. and Tschan, F. (2013), "Moderating effects of attributions on the relationship between emotional dissonance and surface acting: a transactional approach to health care professionals' emotion work", Journal of Applied Social Psychology, Vol. 43 No. 3, pp. 570-581.

Cunliffe, A.L. (2011), "Crafting qualitative research: Morgan and Smircich 30 years on”, Organizational Research Methods, Vol. 14 No. 4, pp. 647-673.

Cunliffe, A.L., Luhman, J.T. and Boje, D.M. (2004), "Narrative temporality: Implications for organizational research", Organization Studies, Vol. 25 No. 2, pp. 261-286.

Denzin, N.K. (2007), On Understanding Emotion, Transaction Publishers, New Jersey.

Edwards, E. (2002), "Material beings: Objecthood and ethnographic photographs", Visual Studies, Vol. 17 No. 1, pp. 67-75.

Edwards, E. and Hart, J. (2004), "Introduction: Photographs as objects", in Edwards, E. and Hart, J. (Eds.), Photographs Objects Histories: On the Materiality of Images, Routledge, Abingdon, pp.1-15.

Fineman, S. (2003), Understanding Emotion at Work, Sage, London.

Fineman, S. (2005), "Appreciating emotion at work: paradigm tensions", International Journal of Work Organisation and Emotion, Vol. 1 No. 1, pp. 4-19.

Fisher, W.R. (1984), "Narration as a human communication paradigm: The case of public moral argument”, Communication Monographs, Vol. 51 No. 1, pp. 1-22.

Folkman, S., Lazarus, R.S., Dunkel-Schetter, C., DeLongis, A. and Gruen, R.J. (1986), "Dynamics of a stressful encounter: Cognitive appraisal, coping, and encounter outcomes", Journal of Personality and Social Psychology, Vol. 50 No. 5, pp. 992-1003.

Fredrickson, B.L. (2003), "Positive emotions and upward spirals in organisations", In Cameron, K.S., Dutton, J.E. and Quinn, R.E. (Eds.), Positive Organizational Scholarship, Berrett-Koehler, San Francisco, CA, pp. 163-175.

Frost, P.J. (2003), Toxic emotions at work: How compassionate managers handle pain and conflict, Harvard Business School Press, Boston, MA.

Garnefski, N, Kraaij, V. and Spinhoven, P. (2001), "Negative life events, cognitive emotion regulation and emotional problems", Personality and Individual Differences, Vol. 30 No. 8, pp. 1311-1327.

Goleman, D. (1995), Emotional Intelligence. Why it can matter more than IQ, Bloomsbury, London. 
Grandey, A.A. and Gabriel, A.S. (2015), "Emotional labor at a crossroads: Where do we go from here?", Annual Review of Organizational Psychology and Organizational Behavior, Vol. 2 No. 1, pp. 323-349.

Gross, J.J. (1999), “Emotion regulation: Past, present, future”, Cognition and Emotion, Vol. 13 No. 5, pp. 551-573.

Harper, D. (2002), "Talking about pictures: A case for photo elicitation”, Visual Studies, Vol. 17 No. 1, pp. 13-26.

Hiillos, M. (2004), "Personnel managers and crisis situations: emotion handling strategies", PhD Thesis. Swedish school of Economics and Business Administration, available at: https://helda.helsinki.fi/bitstream/handle/10227/108/136-951-555-8557.pdf?sequence=2 (accessed 2 September 2017).

Hochschild, A.R. (1983), The Managed Heart. Commercialization of Human Feeling, University of California Press, Berkley, CA.

Hope-Hailey, V., Farndale, E. and Truss, C. (2005), "The HR department's role in organizational performance", Human Resource Management Journal, Vol. 15 No.3, pp. 49-66.

Höykinpuro, R. and Ropo, A. (2014), "Visual narratives on organizational space", Journal of Organizational Change Management, Vol. 27 No. 5, pp. 780-792.

Humphrey, R.H., Ashforth, B.E. and Diefendorff, J.M. (2015), "The bright side of emotional labor", Journal of Organizational Behavior, Vol. 36 No. 6, pp. 749-769.

Johnsen, R. and Gudmand-Høyer, M. (2010), "Lacan and the lack of humanity in HRM", Organization, Vol. 17 No. 3, pp. 331-344.

Jones, C. and Saundry, R. (2012), "The practice of discipline: evaluating the roles and relationship between managers and HR professionals", Human Resource Management Journal, Vol. 22 No. 3, pp. 252-266.

Keegan, A. and Francis, H. (2010), "Practitioner talk: the changing textscape of HRM and emergence of HR business partnership", The International Journal of Human Resource Management, Vol. 21 No. 6, pp. 873-898.

Korczynski, M. (2003), "Communities of coping: collective emotional labour in service work", Organization, Vol. 10 No.1, pp. 55-79.

Kowalski, T.H.P. and Loretto, W. (2017), "Well-being and HRM in the changing workplace", The International Journal of Human Resource Management, Vol. 28 No.16, pp. 2229-2255.

Kulik, C.T., Cregan, C., Metz, I. and Brown, M. (2009), "HR managers as toxin handlers: The buffering effect of formalizing toxin handling responsibilities", Human Resource Management, Vol. 48 No. 5, pp. 695-716.

Legge, K. (1978), Power, innovation and problem solving in personnel management. McGraw-Hill, Maidenhead. 
Lindgren, M., Packendorff, J. and Sergi, V. (2014), "Thrilled by the discourse, suffering through the experience: Emotions in project-based work", Human Relations, Vol. 67 No.11, pp. 1383-1412.

Maitlis, S. (2012), "Narrative analysis", in Symon, G. and Cassell, C. (Eds.), Qualitative Organizational Research, Sage, London, pp. 492-511.

Mann, S. (2004), “People-work': emotion management, stress and coping”, British Journal of Guidance and Counselling, Vol. 32 No. 2, pp. 205-221.

Marchington, M. and Wilkinson, A. (2012), Human resource management at work, $5^{\text {th }}$ ed., CIPD, London.

McMurray, R. and Ward, J. (2014), "'Why would you want to do that?' Defining emotional dirty work", Human Relations, Vol. 6 No. 9, pp. 1123-1143.

Metz, I., Brown, M., Cregan, C. and Kulik, C. (2014), “'Toxin handling' and wellbeing: The case of the human resources manager", European Journal of Work and Organizational Psychology, Vol. 23 No. 2, pp. 248-262.

Meyer, R.E., Höllerer, M.A., Jancsary, D. and Van Leuuwen, T. (2013), "The visual dimension in organizing, organization, and organization research: core ideas, current developments, and promising avenues", The Academy of Management Annals, Vol. 7 No. 1 , pp. $489-555$.

Monat, A. and Lazarus, R.S. (1991), Stress and Coping: An Anthology, Columbia University Press, New York.

O'Brien, E. and Linehan, C. (2014), "A balancing act: emotional challenges in the HR role”, Journal of Management Studies, Vol. 51 No. 8, pp. 1257-1285.

O'Brien, E. and Linehan, C. (2018), "The last taboo?: surfacing and supporting emotional labour in HR work", The International Journal of Human Resource Management, Vol. 2 No. 4, pp. 683-709.

O'Connor, E.S. (2000), "Plotting the organization: The embedded narrative as a construct for studying change", The Journal of Applied Behavioural Science, Vol. 36 No. 2, pp. 174-192.

Parkinson, B. (1996), "Emotions are social”, British Journal of Psychology, Vol. 87 No. 4, pp. 663-683.

Renwick, D. (2003), "HR managers. Guardians of employee wellbeing?", Personnel Review, Vol. 32 No. 3, pp. 341-359.

Richter, M.R., König, C.J., Koppermann, C., Schilling, M. (2016), “Displaying fairness while delivering bad news: testing the effectiveness of organizational bad news training in the layoff context", Journal of Applied Psychology, Vol. 101 No. 6, pp. 779792.

Riessman, C.K. (2002), "Analysis of personal narratives", in Gubrium, J. and Holstein, J. (Eds.), Handbook of Interview Research, Sage, CA, Thousand Oaks, pp. 331-346. 
Riessman, C.K. (2008), Narrative methods for the human sciences, Sage, London.

Sandholtz, K.W. and Burrows, T.N. (2016), "Compliance police or business partner? Institutional complexity and occupational tensions in human resource management", in Cohen, L., Burton, M.D. and Lounsbury, M. (Eds.), The Structuring of Work in Organizations, Vol. 47, Emerald, pp. 161-191.

Scollon, C.N., Koh, S., and Au, E.W.M., (2011), "Cultural differences in the subjective experience of emotion: When and why they occur", Social and Personality Psychology Compass, Vol. 5 No. 11, pp. 853-864.

Sheehan, C., De Cieri, H., Greenwood, M. and Van Buren III, H.J. (2014), "HR professional role tensions: perceptions and responses of the top management team", Human Resource Management, Vol. 53 No. 1, pp. 115-130.

Shortt, H. and Warren, S. (2012), "Fringe benefits: valuing the visual in narratives of hairdressers' identities at work", Visual Studies, Vol. 27 No.1, pp. 18-34.

Shortt, H. and Warren, S. (2017), "Grounded visual pattern analysis: Photographs in organizational field studies", Organizational Research Methods doi:10.1177/1094428117742495

Slutskaya, N. Simpson, A. and Hughes, J. (2012), "Lessons from photoelicitation: encouraging working men to speak", Qualitative Research in Organizations, Vol. 7 No. 1, pp. 16-33.

Smith, B. (2015), "Narrative analysis", in Lyons, E. and Coyle, A. (Eds.), Analysing Qualitative Data in Psychology, Sage, London, pp. 35-60.

Steers, I. (2009), "The conscientious HR manager and the Rubik's Cube”, Personnel Review, Vol. 38 No. 6, pp. 605-620.

Stroebaek, P.S. (2013), "Let's have a cup of coffee! Coffee and coping communities at work", Symbolic Interaction, Vol. 36 No. 4, pp. 381-397.

Sturdy, A. (2003), "Knowing the unknowable? A discussion of methodological and theoretical issues in emotion research and organizational studies", Organization, Vol. 10 No. 1, pp. 81-105.

Theodosius, C. (2006), "Recovering emotion from emotion management", Sociology, Vol. 40 No.5, pp. 893-910.

Turner, J.H. (2009), "The sociology of emotions: Basic theoretical arguments", Emotion Review, Vol. 1 No. 4, pp. 340-354.

Ulrich, D. (1997), Human Resource Champions, Harvard Business School Press, Boston, MA.

Ulrich, D. and Brockbank, W. (2005), The HR Value Proposition, Harvard Business School Press, Boston, MA.

Ulus, E. and Gabriel, Y. (2016), "Bridging the contradictions of social constructionism and psychoanalysis in a study of workplace emotions in India", Culture and Organization, doi: 10.1080/14759551.2015.1131688. 
Warren, S. (2018), "Photography in qualitative organizational research: conceptual, analytical and ethical issues in photo-elicitation inspired methods", in Cassell, C., Cunliffe, A.L. and Grandy, G. (Eds.), The SAGE Handbook of Qualitative Business and Management Research Methods, Sage, London, pp. 239-261.

Wierzbicka, A. (2009), "Language and metalanguage: Key issues in emotion research", Emotion Review, Vol. 1 No. 1, pp. 3-14.

Yang, I. and Kelly, A. (2015), "The positive outcomes of 'socially sharing negative emotions' in workteams: a conceptual exploration”, European Management Journal, Vol. 34 No.2, pp. 172-181. 
Photographs for paper titled 'Navigating emotion in HR work: Caring for ourselves?'

\section{Photograph 1}

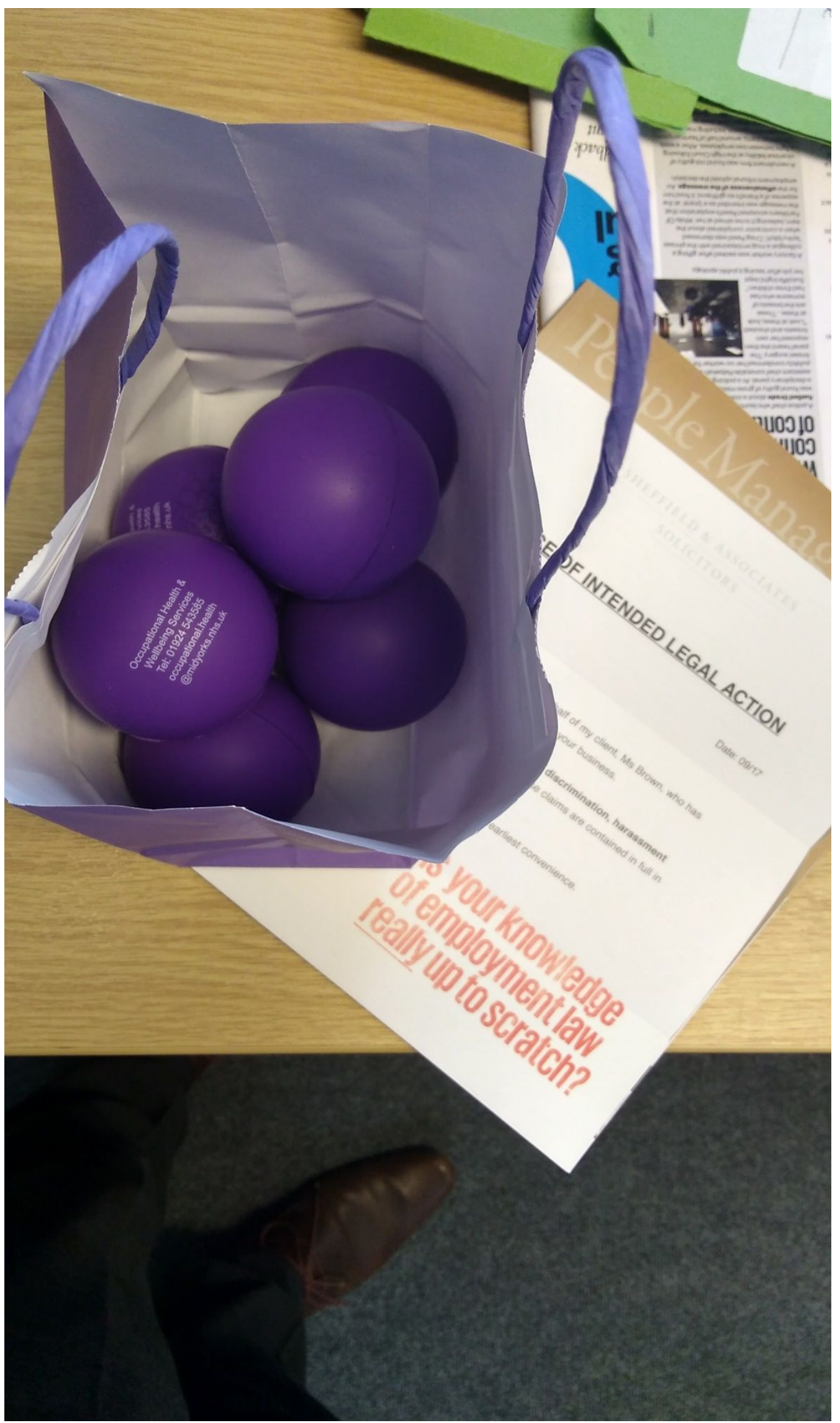


Photographs for paper titled 'Navigating emotion in HR work: Caring for ourselves?'

\section{Photograph 2}

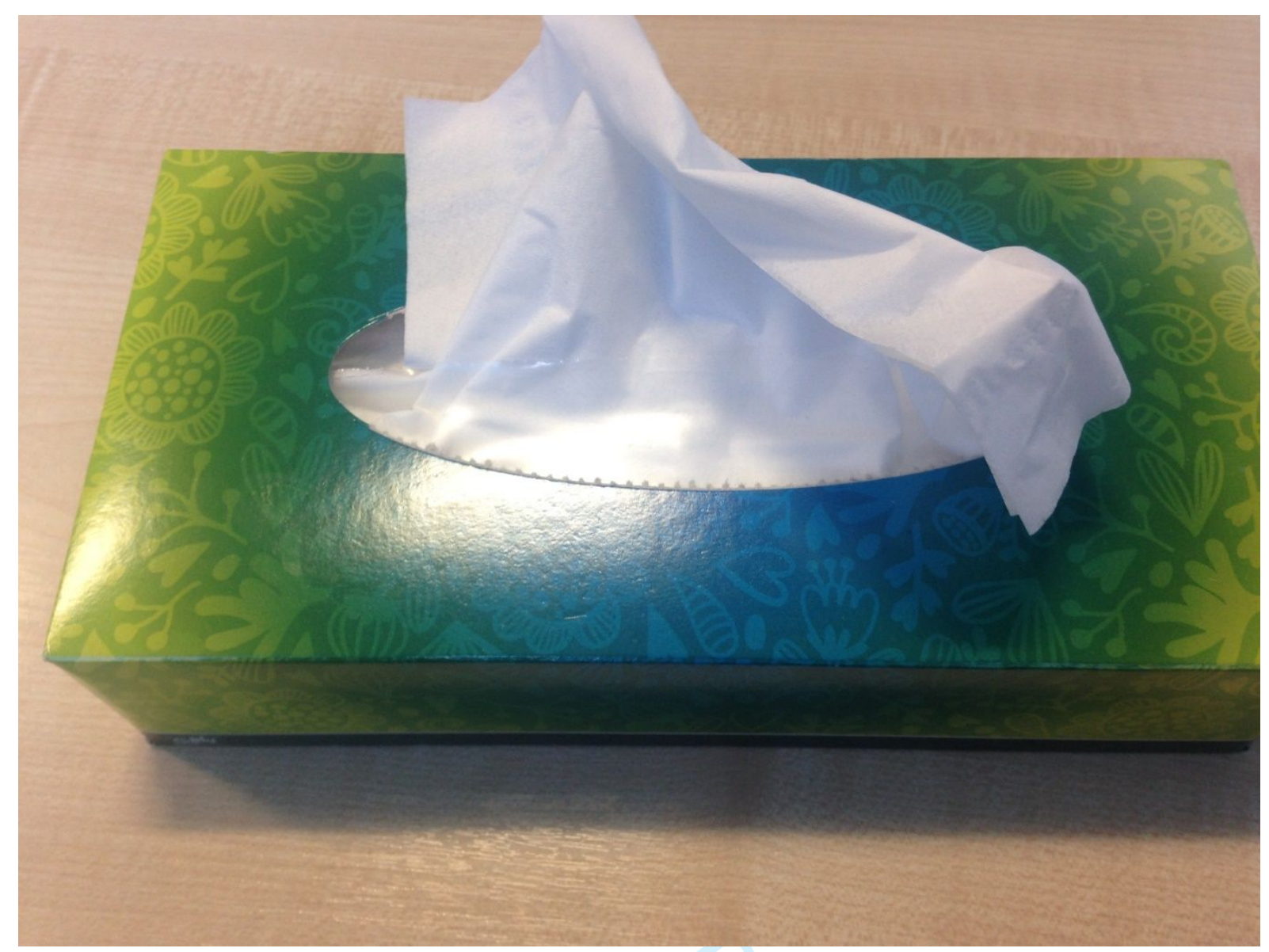


Personnel Review

Page 32 of 42

1
2
3
4
5
6
7
8
9
10
11
12
13
14
15
16
17
18
19
20
21
22
23
24
25
26
27
28
29
30
31
32
33
34
52
53
55
56
57
37
38
38
39
40
41
42
43
44
50

Photographs for paper titled 'Navigating emotion in HR work: Caring for ourselves?'

Photograph 3 